\title{
A Journey from Garbage House to Green House
}

\author{
Viralbhai A Prajapati ${ }^{1}$, Kushal Nandi², Amrita Chakraborty², Dhrubo Jyoti Sen², Pankil Pathak ${ }^{3}$ \\ and Dhananjoy Saha ${ }^{4 *}$
}

${ }^{1} \mathrm{~KB}$ Institute of Pharmaceutical Education \& Research, India

${ }^{2}$ Department of Pharmaceutical Chemistry, School of Pharmacy, Techno India University, India

${ }^{3}$ Shri Sarvajanik Pharmacy College, Gujarat Technological University, India

${ }^{4}$ Deputy Director, Directorate of Technical Education, India

*Corresponding author: Dhrubo Jyoti Sen, Department of Pharmaceutical Chemistry, School of Pharmacy, Techno India University,

Salt Lake City, Sector-V, EM-4, Kolkata-700091, West Bengal, India

\begin{tabular}{|c|c|}
\hline ARTICLE INFO & ABSTRACT \\
\hline Received: 仹 August 14, 2021 & $\begin{array}{l}\text { Every thing in this world has some life span after finishing its life time. Each thing is } \\
\text { not immortal as each entity has some half-life \& self-life. Kinetics is running in each thing }\end{array}$ \\
\hline Published: 蔧 August 24, 2021 & $\begin{array}{l}\text { because nothing in this world is free from chemistry. Each thing in this world is made } \\
\text { of chemical entity either it is organic or inorganic. All materials are made of chemical }\end{array}$ \\
\hline $\begin{array}{l}\text { tation: Viralbhai A Prajapati, Kushal } \\
\text { andi, Amrita Chakraborty, Dhrubo Jyoti } \\
\text { en, Pankil Pathak, Dhananjoy Saha. A } \\
\text { urney from Garbage House to Green }\end{array}$ & $\begin{array}{l}\text { molecule which undergoes to become waste after going into garbage. Bin is of two types: } \\
\text { dustbin (in house \& out house) \& recycle bin (software). Recycling of waste from dustbin } \\
\text { or recycle bin can be further utilised by the point of green chemistry approach and after } \\
\text { that the substance when crosses self-life then can't be further utilised and finally comes }\end{array}$ \\
\hline
\end{tabular}

Keywords: Waste; Debris; Sewage; Effluent; Disposal; Dustbin; Garbage

\section{Overview}

Waste comes in many different forms and may be categorized in a variety of ways. The types listed here are not necessarily exclusive and there may be considerable overlap so that one waste entity may fall into one-to-many types [1-6].
1. Agricultural waste
2. Animal by-products
3. Biodegradable waste
4. Biomedical waste
5. Bulky waste
6. Business waste
7. Chemical waste
8. Clinical waste
9. Coffee wastewater
10. Commercial waste
11. Composite waste
12. Construction and demolition waste (C\&D waste)
13. Consumable waste
14. Controlled waste
15. Demolition waste
16. Dog waste
17. Domestic waste
18. Electronic waste (e-waste)
19. Food waste
20. Gaseous wastes 
21. Green waste

22. Grey water

23. Hazardous waste

24. Household waste

25. Household hazardous waste

26. Human waste

27. Sewage sludge

28. Industrial waste

29. Slag

30. Fly ash

31. Sludge

32. Inert waste

33. Inorganic waste

34. Kitchen waste

35. Litter

36. Liquid waste

37. Marine debris

38. Medical waste

39. Metabolic waste

40. Mineral waste

41. Mixed waste

42. Municipal solid waste

43. Nuclear waste

44. Organic waste

45. Packaging waste

46. Post-consumer waste

47. Radioactive waste

48. Low level waste

49. High level waste

50. Mixed waste (radioactive/hazardous)

51. Spent nuclear fuel

52. Recyclable waste

53. Residual waste
54. Retail hazardous waste

55. Sewage

56. Sharps waste

57. Ship disposal

58. Slaughterhouse waste

Special waste Biomedical waste or hospital waste is any kind of waste containing infectious (or potentially infectious) materials. It may also include waste associated with the generation of biomedical waste that visually appears to be of medical or laboratory origin (e.g. packaging, unused bandages, infusion kits etc.), as well research laboratory waste containing biomolecules or organisms that are mainly restricted from environmental release. As detailed below, discarded sharps are considered biomedical waste whether they are contaminated or not, due to the possibility of being contaminated with blood and their propensity to cause injury when not properly contained and disposed. Biomedical waste is a type of biowaste. There are generally 4 different kinds of medical waste: infectious, hazardous, radioactive, and general. Disposal of this waste is an environmental concern, as many medical wastes are classified as infectious or biohazardous and could potentially lead to the spread of infectious disease. The most common danger for humans is the infection which also affects other living organisms in the region. Daily exposure to the wastes (landfills) leads to accumulation of harmful substances or microbes in the person's body.

1. Red Bag: Syringes (without needles), soiled gloves, catheters, IV tubes etc. should be all disposed of in a red colored bag, which will later be incinerated.

2. Yellow Bag: All dressings, bandages and cotton swabs with body fluids, blood bags, human anatomical waste, body parts are to be discarded in yellow bags.

3. Cardboard box with blue marking: Glass vials, ampules, other glass ware is to be discarded in a cardboard box with a blue marking/sticker.

4. White Puncture Proof Container (PPC): Needles, sharps, blades are disposed of in a white translucent puncture proof container [7-12].

5. Black Bags: These are to be used for non-bio-medical waste. In a hospital setup, this includes stationary, vegetable and fruit peels, leftovers, packaging including that from medicines, disposable caps, disposable masks, disposable shoe-covers, disposable tea cups, cartons, sweeping dust, kitchen waste etc (Figure 1). 

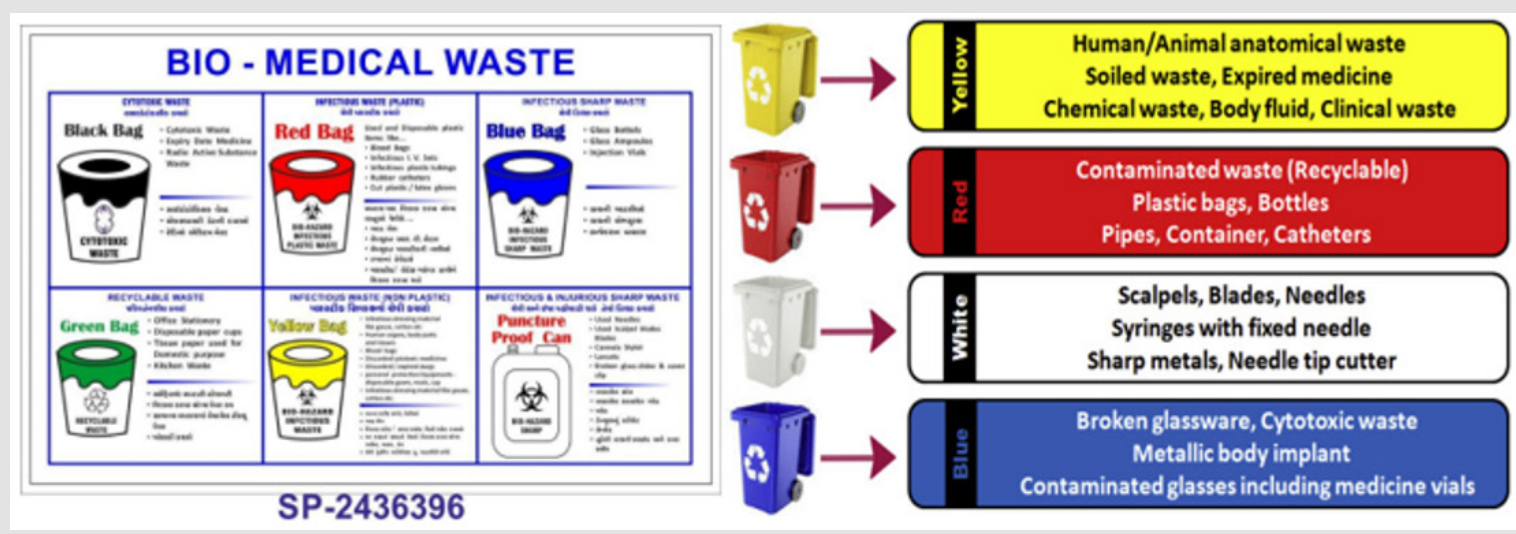

Figure 1: Classification of wastes.

Human waste (or human excreta) refers to the waste products of the human digestive system, menses, and human metabolism including urine and faeces. As part of a sanitation system that is in place, human waste is collected, transported, treated and disposed of or reused by one method or another, depending on the type of toilet being used, ability by the users to pay for services and other factors. Faecal sludge management is used to deal with fecal matter collected in on-site sanitation systems such as pit latrines and septic tanks. The sanitation systems in place differ vastly across the world, with many people in developing countries having to resort to open defecation where human waste is deposited in the environment, for lack of other options. Improvements in "water, sanitation and hygiene" (WASH) around the world is a key public health issue within international development and is the focus of Sustainable Development Goal [6]. People in developed countries tend to use flush toilets where the human waste is mixed with water and transported to sewage treatment plants. Children's excreta can be disposed of in diapers and mixed with municipal solid waste. Diapers are also sometimes dumped directly into the environment, leading to public health risks [13-17].

Electronic waste or e-waste describes discarded electrical or electronic devices. Used electronics which are destined for refurbishment, reuse, resale, salvage recycling through material recovery, or disposal are also considered e-waste. Informal processing of e-waste in developing countries can lead to adverse human health effects and environmental pollution. Electronic scrap components, such as CPUs, contain potentially harmful materials such as lead, cadmium, beryllium, or brominated flame retardants. Recycling and disposal of e-waste may involve significant risk to health of workers and their communities. Biomedical waste must be properly managed and disposed of to protect the environment, general public and workers, especially healthcare and sanitation workers who are at risk of exposure to biomedical waste as an occupational hazard. Steps in the management of biomedical waste include generation, accumulation, handling, storage, treatment, transport and disposal. The development and implementation of a national waste management policy can improve biomedical waste management in health facilities in a country.

\section{On-Site Versus Off-Site}

Two people wearing full protective clothing move a plastic trash bag into a marked spot, while their trainer watches them. their trainer. These healthcare workers are being trained to safely handle contaminated wastes before being assigned to an outbreak of Ebola hemorrhagic fever. Disposal occurs off-site, at a location that is different from the site of generation. Treatment may occur on-site or off-site. On-site treatment of large quantities of biomedical waste usually requires the use of relatively expensive equipment, and is generally only cost effective for very large hospitals and major universities who have the space, labour and budget to operate such equipment. Off-site treatment and disposal involves hiring of a biomedical waste disposal service (also called a truck service) whose employees are trained to collect and haul away biomedical waste in special containers (usually cardboard boxes, or reusable plastic bins) for treatment at a facility designed to handle biomedical waste.

\section{Generation and Accumulation}

Biomedical waste should be collected in containers that are leak-proof and sufficiently strong to prevent breakage during handling. Containers of biomedical waste are marked with a biohazard symbol. The container, marking, and labels are often red. Discarded sharps are usually collected in specialized boxes, often called needle boxes. Specialized equipment is required to meet OSHA 29 CFR 1910.1450[5] and EPA 40 CFR 264.173 [6]. standards of safety. Minimal recommended equipment include a fume hood and primary and secondary waste containers to capture potential overflow. Even beneath the fume hood, containers containing chemical contaminants should remain closed when not in use. An open funnel placed in the mouth of a waste container has been shown to allow significant evaporation of chemicals into the surrounding 
atmosphere, which is then inhaled by laboratory personnel, and contributes a primary component to the threat of completing the fire triangle. To protect the health and safety of laboratory staff as well as neighboring civilians and the environment, proper waste management equipment, such as the Burkle funnel in Europe and the ECO Funnel in the U.S., should be utilized in any department which deals with chemical waste. It is to be dumped after treatment [18-20] (Figure 2).
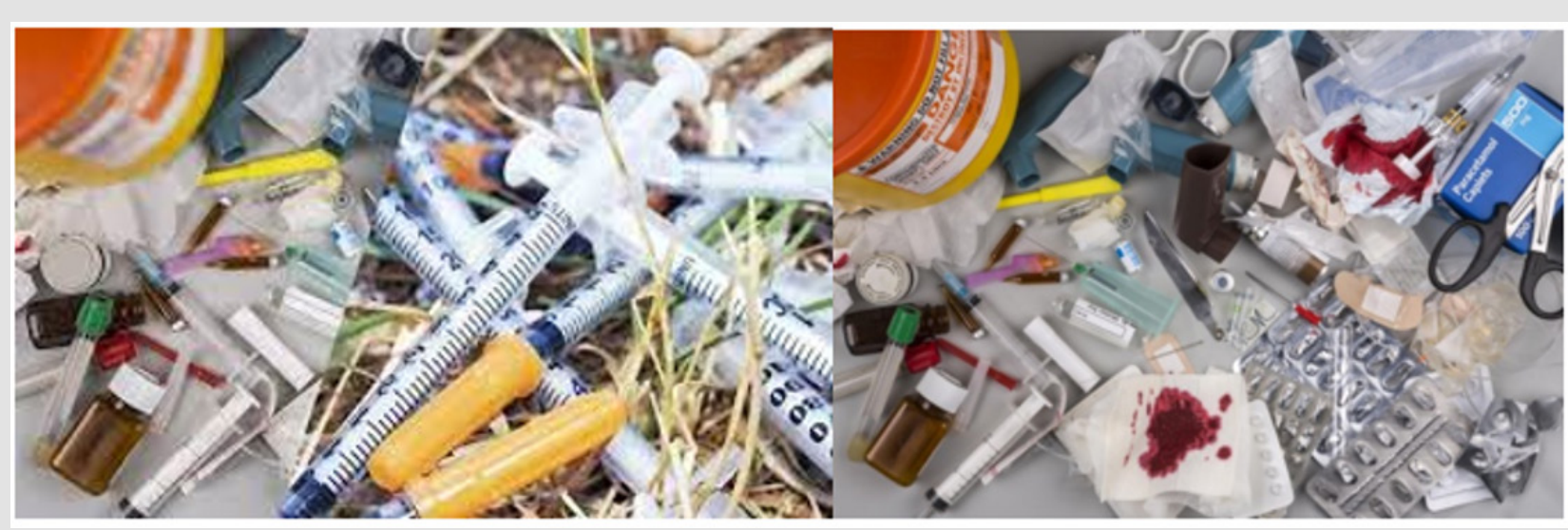

Figure 2: Biomedical waste.

\section{Storage \& Handling}

Storage refers to keeping the waste until it is treated on-site or transported off-site for treatment or disposal. There are many options and containers for storage. Regulatory agencies may limit the time for which waste can remain in storage. Handling is the act of moving biomedical waste between the point of generation, accumulation areas, storage locations and on-site treatment facilities. Workers who handle biomedical waste must observe standard precautions.

\section{Treatment}

The goals of biomedical waste treatment are to reduce or eliminate the waste's hazards, and usually to make the waste unrecognizable. Treatment should render the waste safe for subsequent handling and disposal. There are several treatment methods that can accomplish these goals. It includes segregating the bio waste. Biomedical waste is often incinerated. An efficient incinerator will destroy pathogens and sharps. Source materials are not recognizable in the resulting ash. Alternative thermal treatment can also include technologies such as gasification and pyrolysis including energy recovery with similar waste volume reductions and pathogen destruction. An autoclave may also be used to treat biomedical waste. An autoclave uses steam and pressure to sterilize the waste or reduce its microbiological load to a level at which it may be safely disposed of. Many healthcare facilities routinely use an autoclave to sterilize medical supplies. If the same autoclave is used to sterilize supplies and treat biomedical waste, administrative controls must be used to prevent the waste operations from contaminating the supplies. Effective administrative controls include operator training, strict procedures, and separate times and space for processing biomedical waste. Microwave disinfection can also be employed for treatment of Biomedical wastes. Microwave irradiation is a type of non-contact heating technologies for disinfection. Microwave chemistry is based on efficient heating of materials by microwave dielectric heating effects.

When exposed to microwave frequencies, the dipoles of the water molecules present in cells re-align with the applied electric field. As the field oscillates, the dipoles attempts to realign itself with the alternating electric field and in this process, energy is lost in the form of heat through molecular friction and dielectric loss. Microwave disinfection is a recently developed technology which provides advantage over old existing technologies of autoclaves as microwave-based disinfection has less cycle time, power consumption and it requires minimal usage of water and consumables as compared to autoclaves. For liquids and small quantities, a $1-10 \%$ solution of bleach can be used to disinfect biomedical waste. Solutions of sodium hydroxide and other chemical disinfectants may also be used, depending on the waste's characteristics. Other treatment methods include heat, alkaline digesters and the use of microwaves. For autoclaves and microwave systems, a shredder may be used as a final treatment step to render the waste unrecognizable. Some autoclaves have built in shredders [21-24].

\section{Conclusion}

It is agreed that wastes is a direct result of human interaction and activities. Nevertheless, there seems to be several opinions as to what constitute a waste. Several researchers however agreed that wastes are materials whose owners no longer have a need for. Therefore, it is obvious that wastes are indeed subjective in meaning, as the term is open to several interpretations and also influenced by personal opinion. Nevertheless, it is important 
to provide a definition or at least a guide for the purposes of policies and legislations. This is evident from the fact that, it is the knowledge of what specifically constitute a waste and the categories of wastes that determines how wastes are dealt with or managed. Waste management involves a process whereby wastes are collected, transported and disposed of in the best possible way of limiting or eliminating the harmful effect of wastes. This aspect of environmental management is as important as other public amenities or infrastructures without which the life of contemporary man would be extremely difficult. This is because studies have shown a direct link between air, water and land pollution and diseases such as lung cancer, heart disease, cholera and hepatitis. In addition, climate change and eutrophication are a direct result of water and air pollution. Little wonder why there is a huge disparity in the life expectancy of people in developed and developing countries. Since factors such as population increase and the coming together of people to form communities lead to increase waste generation. Efforts should be directed towards making projections far ahead in order to ensure that new and existing settlements are adequately planned so as to accommodate possible increase in the volume of waste generation in future. Effectively planning ahead will prevent indiscriminate disposal and other harmful practices so as to prevent the build-up of open dumps and breeding ground for rats and other vermin which poses health risk.

\section{References}

1. Aye L, Widjaya ER (2006) Environmental and economic analyses of waste disposal options for traditional markets in Indonesia. Waste Management 26(10): 1180-1191.

2. Barros AI, Dekker R, Scholten V (1998) A two-level network for recycling sand: A case study. European Journal of Operational Research 110(2): 199-214.

3. Basu R (2009) Solid Waste Management-A Model Study. Sies Journal of Management 6: 20-24.

4. Beranek W (1992) Solid Waste Management and Economic Development. Economic Development Review 10: 49. Berkun M, Aras E, Anlan T (2011). Solid waste management practices in Turkey. Journal of Material Cycles and Waste Management 13(4): 305-313.

5. Brunner PH, Rechberger H (2014) Waste to energy-key element for sustainable waste management. Waste Management 37: 3-12.

6. Buah WK, Cunliffe AM, Williams PT (2007) Characterization of Products from the Pyrolysis of Municipal Solid Waste. Process Safety \& Environmental Protection 85(5): 450-457.

7. Chan WW, Lam J (2001) Environmental Accounting of Municipal Solid Waste Originating from Rooms and Restaurants in the Hong Kong Hotel Industry. Journal of Hospitality \& Tourism Research 25(4): 371-385.
8. Chandler AJ, Eighmy TT, Hjelmar O, Kosson DS, Sawell SE, et al. (1997) Municipal Solid Waste Incinerator Residues. Journal of Management and Sustainability.

9. Reuter MA, Verhoef EV (2000) A new paradigm for waste management. Waste Management 20(8): 633-638. Dixon N, Jones DRV (2005). Engineering properties of municipal solid waste. Geotextiles \& Geomembranes 23(3): 205-233.

10. Erdogan N, Baris E (2007) Environmental protection programs and conservation practices of hotels in Ankara, Turkey. Tourism Management 28(2): 604-614.

11. Faniran 00, Caban G (1998) Minimizing waste on construction project sites. Engineering, Construction and Architectural Management 5(2): 182-188.

12. Ghiani G, Laganà D, Manni E, Musmanno R, Vigo D (2014) Operations research in solid waste management: A survey of strategic and tactical issues. Computers \& Operations Research 44(4): 22-32.

13. Giusti L (2009) A review of waste management practices and their impact on human health. Waste Management 29(8): 2227-2239.

14. Jaillon L, Poon CS, Chiang YH (2009) Quantifying the waste reduction potential of using prefabrication in building construction in Hong Kong. Waste Management 29(1): 309-320.

15. Kaseva ME, Gupta SK (1996) Recycling-an environmentally friendly and income generating activity towards sustainable solid waste management. Case study-Dar es Salaam City, Tanzania. Resources Conservation \& Recycling 17(4): 299-309.

16. Kasim A (2007) Towards a Wider Adoption of Environmental Responsibility in the Hotel Sector. International Journal of Hospitality \& Tourism Administration 8(2): 25-49.

17. Marchettini N, Ridolfi R, Rustici M (2007) An environmental analysis for comparing waste management options and strategies. Waste Management 27(4): 562-571.

18. Mcdonald B, Smithers M (1998) Implementing a waste management plan during the construction phase of a project: a case study. Construction Management \& Economics 16(1): 71-78.

19. Schnitzer H (2009) Sustainable solutions for solid waste management in Southeast Asian countries. Waste Management 29(6): 1982-1995.

20. Norrie J, Lafortune P, Beauchamp CJ (1997) Characterization of waste materials originating from Quebec supermarkets and an assessment of recycling potential. Resources Conservation \& Recycling 19(4): 265-277.

21. Ochoa A, Duarte M, Bueno L, Salas B, Alpírez G, et al. (2010) Systemic Analysis of Supermarket Solid Waste Generation in Mexicali, Mexico. Journal of Environmental Protection 1(2): 105-110.

22. Ogwueleka T (2009) Municipal solid waste characteristics and management in Nigeria. Iranian Journal of Environmental Health Science \& Engineering 6(3): 173-180.

23. Poon CS, Yu AT W, Ng LH (2001) On-site sorting of construction and demolition waste in Hong Kong. Resources Conservation \& Recycling 32(5): 157-172.

24. Radwan HR I, Jones E, Minoli D (2010) Managing solid waste in small hotels. Journal of Sustainable Tourism 18(2): 175-190. 
ISSN: 2574-1241

DOI: 10.26717/BJSTR.2021.38.006142

Dhananjoy Saha. Biomed J Sci \& Tech Res

(c) (P) This work is licensed under Creative

Submission Link: https://biomedres.us/submit-manuscript.php

$\begin{array}{ll}\text { BIOMEDICAL } & \text { Assets of Publishing with us } \\ \text { RESEARCHES } & \text { Global archiving of articles } \\ \text { - Immediate, unrestricted online access } & \text { - Rigorous Peer Review Process } \\ & \text { - Authors Retain Copyrights }\end{array}$

